\title{
The OECD Report on Pillar One Blueprint and Article 12B in the UN Report
}

\section{Why the DeADLOCK ON POLICY CHOICES IS DAMAGING TECHNICAL WORK}

The news on the eve of 2021 on taxation of the digital economy or the reform of the international tax system is the lack of political consensus. The aphorism of No news is good news is not applicable to the current situation in international tax law as the latter urgently requires reform. In spite of the lack of consensus, technical work is still being carried out by both the $\mathrm{OECD}^{1}$ and the UN. ${ }^{2}$

However, when interpreting the contents and proposals of this technical work, it can be easily concluded that it reflects the deadlock in political agreement. Two notes can be highlighted in assessing the aforementioned technical work: one is positive and the other is negative.

The positive note is that both the G20/OECD and the UN are heading towards similar directions in terms of both acknowledging allocation of taxing rights to the market state and the need to explicitly cover taxation of automated digital services, ${ }^{3}$ including monetization of data.

The negative note is connected with the lack of consensus on the scope of taxing rights allocated to market countries, the inconsistency of the proposals with the announced guiding principles, and the resulting complexity. ${ }^{4}$

The Blueprint finds it necessary to differentiate between automated digital services and consumer-facing business. ${ }^{5}$ Stated differently, it considers extending the scope of taxing rights by the market states and going beyond consumer-facing business (CFB) which is different than what had been foreseen in Pillar One. Amount A would now cover the CFB and income from automated digital services (ADS): both would be 'in-scope activities'.

In turn, the UN Committee of Experts on International Cooperation in Tax Matters proposes introducing a new provision 12B (Income from Automated Digital Services) ${ }^{6}$ without finding it necessary to include an autonomous concept of the CFB and going beyond the recent Article $12 \mathrm{~A}$ that focuses on fees.

Both moves appear to acknowledge the necessity of introducing what was previously referred to as short-term measures. ${ }^{7}$ They concern not only taxation of the CFB in the market state as they go beyond the CFB and allegedly attribute taxing rights to the market state because the economy is progressively becoming digitalized. Enterprises of one contracting state are increasingly providing substantial services to customers in the other contracting state and maintaining a significant economic presence there without having any fixed place of business and without being present in that state for any substantial period of time.

\section{Preference to net taxation where APPLICABLE AND AVOIDING DOUBLE TAXATION AND NON-TAXATION}

Moreover, the OECD Secretary-General Tax Report to G20 Finance Ministers and Central Bank Governors, Saudi Arabia, October $2020^{8}$ and the Proposed Article 12B of the UN Model Convention' allegedly rely on guiding principles and objectives, specifically:

\section{Notes}

OECD, Tax Challenges Arising from Digitalisation - Report on Pillar One Blueprint, OECD/G20 Base Erosion and Profit Shifting Project (OECD Publishing, Oct. 2020).

United Nations, Committee of Experts on International Cooperation in Tax Matters, Tax Consequences of the Digitalized Economy - Issues of Relevance for Developing Countries, E/ C.18/2020/CRP.41 (10 Oct. 2020).

OECD, Report on Pillar One Blueprint, supra n. 1, at 19-20. United Nations, supra n. 2.

S. Greil \& T. Eisgruber, Taxing the Digital Economy - A Case Study on the Unified Approach, 49 Intertax 1 (2021).

OECD, Report on Pillar One Blueprint, supra n. 1, at 19-22.

United Nations, supra n. 2

Y. Brauner, Taxing the Digital Economy Post-BEPS, Seriously, 46(6/7) Intertax 462-465 (2018); A. Báez Moreno, A Note on Some Radical Alternatives to the Existing International Corporate Tax and Their Implications for the Digital(ized) Economy, 46(6/7) Intertax 565-572 (2018); Maarten Floris de Wilde, Tax Policy Responses for the Digitalizing Economy: Fold or All-in, 46(6/7) Intertax 466-475 (2018).

8 OECD, OECD Secretary-General Tax Report to G20 Finance Ministers and Central Bank Governors, Saudi Arabia (OECD Publishing, Oct. 2020).

9 United Nations, supra n. 2. 
1) Avoiding both double taxation and non-taxation;

2) Preferring taxation on a net basis when practicable;

3) Seeking simplicity and administrability. ${ }^{10}$

In spite of the hesitation on the scope, proposals reveal that taxation in the market state of both the CFB and (any other) ADS (excluding some sectors) will imply taxation on gross income. These proposals are possibly an inevitable result of the lack of policy consensus on key issues including the scope of the new taxing rights that are attributable to the market state. Having this in mind, it is more than questionable that technical work can be successfully performed.

Preference to taxation on a net basis when practicable, which is claimed both by the G20/OECD and the UN, would demonstrate reluctance to acknowledge taxing rights to the market state ${ }^{11}$ and lead to inconsistencies and complexity. In contrast to the declaration of net taxation as a guiding principle, it can be traced from the evolution of the G20/OECD and the UN proposals that allocation of taxing rights to the market state does not rely on net taxation. The reason for such inconsistency is the inadequacy of net taxation based on transfer pricing and the arm's length standard when the narrative is about allocation of taxing rights to the market state.

A combination of market state and net taxation could occur either under formulary apportionment at a worldwide level (which is not achievable) or attributing a different international meaning to the arm's length standard. This could, in theory, be similar to the one adopted by the US Ninth Circuit Court under Altera Corp, ${ }^{12}$ which is not a precedent in the United States and does not correspond to its interpretation in other jurisdictions.

Pillar One and the Blueprint on Pillar One as well as the proposal by the UN on a new Article 12B allocate taxing rights to the market state based on gross taxation (Article 12B, paragraph $3^{13}$ ). This combination is required in order to assess the residual profit, which is the basis for attributing taxing rights to the market state.

However, this weakens market states' rights if they are considered as an exception to the net taxation principle and, moreover, a combination of net and gross taxation introduces substantial complexity to the administration of allocation of taxing rights.
Similarly, the search for how much to allocate to the market state on the basis of value creation has led to a frustrating result, and that is probably the reason why it is not mentioned in either the G20/0ECD Pillar One or in the Blueprint. The UN Report in preparation of the eighteenth Session held in New York in April 2019 questions whether value creation is the appropriate basis for attributing taxing rights for the interest of developing countries. $^{14}$

Value creation is inappropriate as a principle for justifying the attribution of taxing rights to the market state, and such inadequacy goes beyond the binomial OECD countries' $v$. developing countries' interests. Value creation is inapplicable as a basis for attributing taxing rights to the market state from the moment the latter is thought to be different from the source state.

In the context of the digital economy, value creation cannot go beyond determining the beneficial owner's automated digital business segment; functions, assets and risks (FAR); and development, enhancement, maintenance, protection and exploitation (DEMPE).

Avoiding both double taxation and non-taxation is not achievable by the Blueprint on Pillar 1. A combination of different amounts and methods will inevitably lead to double taxation, and developing countries will not receive tax revenues.

In this respect, the Blueprint and the UN CoCoordinators' Report on tax consequences of the digitalized economy - issues of relevance for developing countries $^{15}$ - are heading towards similar directions.

\section{SCOPE OF OECD/G20 AMOUNT A AND A new Article I 2B UN Model Tax Convention}

The OECD Unified Approach (Pillar 1) suggested the introduction of a new nexus rule - the market state - in the absence of physical presence that would possibly be restricted to a minimum revenue threshold. ${ }^{16}$ The market state was further related to 'user' states of highly digitalized businesses and to 'consumer-facing business' or 'digital-centric businesses which interact remotely with users' ${ }^{17}$ that would 'not be dependent on physical presence

\section{Notes}

10 For example, OECD, OECD Secretary-General Tax Report, supra n. 8, at 4; United Nations, Committee of Experts on International Cooperation in Tax Matters, Tax Issues Related to the Digitalization of the Economy, E/C.18/2019/CRP.12, 3 (5 Apr. 2019).

11 United Nations, supra n. 2

12 US: CA 9th Cir., 24 July 2018, Altera Corporation E Subsidiaries v. Commissioner of Internal Revenue, No. 16-70496 (9th Cir. 2018).

13 United Nations, supra n. 2, at 9: '... the qualified profits shall be $30 \%$ of the amount resulting from applying the profitability ratio of that beneficial owner's automated digital business segment to the gross annual revenue from automated digital services derived from the Contracting State where such income arise'.

14 United Nations, supra n. 2.

15 Ibid.

16 OECD, Secretariat Proposal for a 'Unified Approach' Under Pillar One, Public Consultation Document 9 Oct. 2019-12 Nov. 2019, 7, mno 20 \& 8 , mno 22 (OECD Publishing 2019).

17 OECD, Public Consultation Document on a Unified Approach, supra n. 16, at 7, mno 19 
but largely dependent on sales'. ${ }^{18}$ A CFB would be taxed as Amount A.

The Report on Pillar One Blueprint submits the application of Amount $A$ to an activity test. In-scope activities are either ADS or a CFB.

Identification of a specific activity in the scope of an ADS accords with a methodology that changes the hierarchy between a general definition (it usually comes first) and examples (normally used to illustrate the concept under the general definition). For the sake of certainty, the Blueprint proposes to first identify an activity on a positive list. If the activity is not on that list, a negative list will clarify whether the activity is excluded. If the activity is not in either list, the interpreter will check whether it falls within the general definition ${ }^{19}$ that will be based on the elements 'automated' and 'digital'. ${ }^{20}$

In the Report on Pillar One Blueprint, the ADS contains nine categories of services, specifically: online advertising services; sale or other alienation of user data; online search engines; online intermediation platform services; social media platforms; digital content services; online gaming; cloud computing services; standardized online teaching services.

This list coincides with the list of examples that is proposed in commentary 38 to the proposed draft for a new Article $12 \mathrm{~B}$ by the UN Committee of Experts on International Cooperation in Tax Matters. ${ }^{21}$

Automated digital services and a consumer-facing business can generate revenue from the monetization of data. ${ }^{22}$ Some automated digital services can coincide with a consumer-facing business, as is the case of social media platforms.

A consumer-facing business is defined as going beyond the ADS. Its characterization focuses on engagement with consumers that leads to substantial improvement of values of products and increase of sales; targeted marketing and branding; and collection and exploitation of consumer data. Furthermore, it is acknowledged that the ADS and a CFB ensure the treatment of business models that are combined. ${ }^{23}$

Excluding some sectors from the scope of Amount A - certain natural resources, certain financial services, construction, sale and leasing of residential property, international air and shipping business - indicates that the Blueprint aims to be a long-term reform.

The proposed draft for a new Article 12B paragraph 1 by the UN Committee of Experts on International
Cooperation in Tax Matters grants taxing rights to the contracting state when 'income from automated digital services' arises and is 'paid to a resident of the other contracting state'. The term 'income from automated digital services' is defined under paragraph 4 of the same article as 'any payment in consideration for any service provided in the internet or an electronic network requiring minimal human involvement from the service provider'. The term 'income from automated digital services', however, does not include payments qualifying as 'royalties' or 'fees for technical services' under Article 12 or Article $12 \mathrm{~A}$ as the case may be.

Commentary number 35 to paragraph 4 clarifies that:

an important indicator of concept of automated is whether there is ability to scale up and provide the same type of service to new users with minimal human involvement ... for many automated digital services businesses, developing the system that delivers the offered service may require a large degree of upfront human involvement and capital inputs such as creating algorithms to deliver the automated service including such features as tailoring the offering to user's preferences.

Furthermore, commentary 38 delivers a list of examples of automated digital services:

'Online advertising services; sale or other alienation of user data; online search engines; online intermediation platform services; social media platforms; digital content services; online gaming; cloud computing services; standardized online teaching services'.

Both Article 12B paragraph 4 and the commentary make it clear that the object of taxation coincides with the Pillar 1 reference to 'consumer-facing business' or 'digital-centric businesses which interact remotely with users'.

\section{Article I2A paragraph 2 of the UN Model Convention 2017}

Article 12B comes as a surprise as Article 12A paragraph 2 of the UN Model Convention introduced in 2017 already grants taxing rights to the market state in respect of fees for technical services. ${ }^{24}$ It seemed to address the

\section{Notes}

18 Ibid., at 5, mno 15

19 OECD, Report on Pillar One Blueprint, supra n. 1, at 19-20.

20 Ibid, at 20.

21 United Nations, supra n. 2, at 18-19.

22 OECD, Report on Pillar One Blueprint, supra n. 1, at 19.

23 Ibid, at 21.

24 ' $\mathrm{f}$ f lees for technical services arising in a Contracting State may also be taxed in the Contracting State in which they arise and according to the laws of that State, but if the beneficial owner of the fees is a resident of the other Contracting State, the tax so charged shall not exceed _ percent of the gross amount of the fees [the percentage to be established through bilateral negotiations]'. United Nations, Model Double Taxation Convention Between Developed and Developing Countries (2017) (UN Model Convention (2017)). 
purpose of a long-term reform of the international tax system by tackling it with a simple measure. ${ }^{25}$

Article $12 \mathrm{~A}$ allows a contracting state to tax fees for certain technical services paid to a resident of the other contracting state if the fees are paid by a resident of that state or by a non-resident with a permanent establishment or fixed base in that state and the fees are borne by the permanent establishment or fixed base. Furthermore, it is not necessary for the technical services to be provided in that state. In the absence of a permanent establishment, taxation will occur on a gross basis at a rate to be negotiated by the contracting states. ${ }^{26}$ Fees for technical services are defined to mean payments for services of a managerial, technical, or consultancy nature.

The commentary to Article $12 \mathrm{~A}$ also further makes reference to the possibility of an enterprise of one contracting state providing substantial services to customers in the other contracting state and, therefore, maintaining a significant economic presence in that state without having any fixed place of business there and without being present in that state for any substantial period. ${ }^{27}$

Article 12A of the UN Model Convention was meant to react to problems identified in the $\mathrm{OECD} / \mathrm{G} 20$ Base Erosion and Profit Shifting Project, Action 1: Final Report 'Addressing the Tax Challenges of the Digital Economy' (2015). Article 12A Commentary illustrates the difficulties faced by tax policymakers and tax administrations in dealing with the new digital business models made available through the digital economy:

The Report did not recommend, for the time being, a withholding tax on digital transactions (which include digital cross border services); nor did it recommend a new nexus for taxation in the form of a significant economic presence test. However, it was recognized that countries were free to include such provisions in their tax treaties, among other additional safeguards against BEPS. ${ }^{28}$

The afore-mentioned purpose of combining net taxation when applicable (traditional residence and source) with gross taxation or presumptive methods in the case of market states is leading to complexity such as combining taxation Amounts A, B, and $\mathrm{C}$ and the UN proposal of a new Article 12B added to Article 12A and net taxation of profits in the event that there is a permanent establishment.

\section{Concluding Remarks}

Both the OECD/G20 and the UN are still attempting to justify their proposals on the basis of principles. However, concrete proposals could hardly be more distant and inconsistent with the announced principles. The reason for such inconsistency is the lack of consensus on attributing taxing rights to the market state and its scope as well as the inadequacy of net taxation based on transfer pricing and the arm's length standard when the narrative is about the allocation of taxing rights to the market state. The broader the scope of taxing rights attributed to market states based on the ADS and CFB, the broader the exception to the net taxation principle.

The common point in the two proposals is the taxation of the ADS. The OECD Blueprint does not include taxation of fees by the market state, and the UN does not propose to tax a CFB as an autonomous concept from the ADS. Taxation of fees by the market state would be the long-term solution that is missing in the OECD/G20 Blueprint.

Ana Paula Dourado Editor-in-Chief

\section{Notes}

25 Brauner/Baez Moreno. Y. Brauner \& A. Baez Moreno, Withbolding Taxes in the Service of BEPS Action 1: Address the Tax Challenges of the Digital Economy, WU International Taxation Research Paper Series No. 2015-14 (2015); A. Báez Moreno \& Y. Brauner, Taxing the Digital Economy Post-BEPS ... Seriously, 59 Colum. J. Transnat'l L. (2019).

26 UN Model Convention (2017), supra n. 24

27 Ibid.

28 UN Model Convention (2017): Commentary on Art. 12a, para. 2, at 319. 